DOI: $10.17957 / \mathrm{IJAB} / 15.1797$

http://www.fspublishers.org

\title{
Host Dependent and Geographical Structuring of Citrus Canker Bacteria at Peshawar, Pakistan
}

\author{
Safi Ullah ${ }^{1}$, Laila Jamshed ${ }^{1}$, Musharaf Ahmed ${ }^{2}$, Zia-ur-Rehman ${ }^{1}$, Aamir Iqbal', Muhammad Zakria ${ }^{3}$, Muhammad \\ Rameez Khan ${ }^{1}$, Mudassar Nawaz Khan ${ }^{1}$, Ijlal Hussain ${ }^{4}$ and Sajid Ali ${ }^{1,5^{*}}$ \\ ${ }^{1}$ Institute of Biotechnology \& Genetic Engineering, The University of Agriculture, Peshawar, Pakistan \\ ${ }^{2}$ Department of Plant Pathology, The University of Agriculture, Peshawar, Pakistan \\ ${ }^{3}$ Crop Disease Research Institute, National Agricultural Research Center, Islamabad, Pakistan \\ ${ }^{4}$ Department of Agriculture (Extension), Gilgit-Baltistan, Pakistan \\ ${ }^{5}$ Department of Agriculture, Hazara University, Mansehra, Pakistan \\ *For correspondence: bioscientist122@yahoo.com \\ Received 07 December 2020; Accepted 24 March 2021; Published 10 May 2021
}

\begin{abstract}
Citrus canker disease, caused by Xanthomonas axonopodis pv. Citri (Xac) induces huge losses to citrus, particularly in nurseries. This study assessed the level of genetic diversity and divergence in Xac population prevalent in district Peshawar on various host species, based on isolates collected from different fruit nurseries of Peshawar. Surveillance resulted in collection of 80 samples, out of which 50 bacterial samples were isolated. Genotyping of the isolates using RAPD markers amplified 35 scorable loci with an average of 8.7 loci per primers and level of polymorphism was $100 \%$, i.e., almost all of the isolates genotyped had a different multilocus genotype. The loci GLA-031000 was recorded with the highest gene diversity (0.51) followed by GLB-05_1000 and GLA-03_1100 (0.49). The maximum diversity index (0.50) was recorded for loci GLA031000, followed by GLB-051000 and GLA-03_1100 (0.48). A high diversity was observed across all locations, with the range of genotypic diversity from 0.778 (detected at Malakandair) to 0.955 (detected at Hayatabad and Tarnab). Divergence between samples collected from different locations was limited as revealed by the PCA, PCoA, phylogenetic tree and network analyses. Samples originated from various hosts also revealed a high diversity across host types with the minimum genotype diversity observed for Eureka Lemon (0.750) and the maximum for sweet lemon (0.966). The divergence for samples collected on various citrus host types was absent. The very small linkage disequilibrium $(0.006-0.159)$ reflected on the potential recombination in the population, which must have direct implications to disease management and resistance exploitation. (C) 2021 Friends Science Publishers
\end{abstract}

Keywords: Xanthomonas axonopodis; Molecular genotyping; Citrus orchards; Population structure

\section{Introduction}

The Citrus genus belongs to sub-tribe Citrinae of family Rutaceae of subfamily Aurantioidease (Araujo et al. 2003), which originated from Monsoon areas and spread out from Pakistan to China, India, Northwest Australia and New Guinea (Ulubelde 1985). Citrus is one the most important of fruit crops that are widely grown in Pakistan, and the country occupied $12^{\text {th }}$ most significant position in citrus production all around the world (Siddique and Garnevska 2018). Pakistan has a total of 206,569 hectares of cultivated areas for citrus, the province of Punjab has the highest citrus production i.e., 2,315895 ton on 183,210 hectares, mainly due to suitable environmental and growing conditions (Memon 2017). The tropical, subtropical and temperate regions with the appropriate climates like the winter temperatures and lack of frost provide suitable environment for the citrus fruit production. In such areas, the suitable soils and sufficient water support the citrus tree growth as well as fruit production (Kahn et al. 2001).

Despite the economic importance of citrus, the countrywide production is always at risk due to diseases. Various diseases could be present on citrus, though the citrus canker is the most common and dangerous diseases for all types of citrus crops (Das 2003). The disease accounts for the significant losses of citrus, and the degree of disease severity varies with pathogen type, host crop and climate conditions (Das 2003). The disease is widespread in India, Japan, Pakistan and other South-East Asian countries from where it has dispersed to the rest of the world except Europe (Schubert and Miller 1996; Das 2003). Commonly, the infection of canker pathogen does not occur in drought condition and has been eradicated from some of such areas. Still, the extensive incidences of the diseases in many areas

To cite this paper: Ullah S, L Jamshed, M Ahmed, Zia-ur-Rehman, A Iqbal, M Zakria, MR Khan, MN Khan, I Hussain, S Ali (2021). Host dependent and geographical structuring of citrus canker bacteria at Peshawar, Pakistan. Intl J Agric Biol 25:1346-1354 
pose a continuous thread to citri-culture in canker free areas, if the pathogen invades into these areas (Das 2003). In US the disease has been important where it did severe damages as millions of diseased trees were cut off or burnt down (Schubert and Miller 1996).

Canker disease symptoms are distinguished by the incidence of noticeable necrotic lesions on leaves, foliage and fruit (Graham and Dewdney 2014). At first, the lesions are of smaller size but later both epidermal areas become ruptured and hyperplasia (increase in cell number) is caused by the pathogen. The circular lesion on stems leaves and fruits rose into yellow or white soft eruptions. These eruptions then change into light tan to brown corky canker (Schubert and Miller 1996). Severe infection may result in defoliation, die-back, deformation and premature fruit drop (Graham and Dewdney 2014). Canker disease causes fruits losses due to abscission of premature fruits, or the canker lesion makes its quality worse that is not acceptable by the fresh market in many parts of the world, including Pakistan (Schubert and Miller 1996).

The disease is distributed worldwide, and is important in Pakistan with different variants prevalent in different parts of the world. The disease was first reported in Oman in 1985. Related pathogenic isolates have been cited in Saudi Arabia, India and Iran (Vernière et al. 1998). There is variability in various isolates in terms of antibiotic resistance in Reunion and islands of Indian Ocean (Graham et al. 2000).

The phytopathogenic bacteria from the genus Xanthomonas infect wide varieties of plants and represent great importance for citrus production (Silva et al. 2002). In specific, Xac $p v$. citri infects smaller numbers of plant species and have limited host range (Leyns et al. 1984). X. axonopodis that causes Asiatic citrus canker is responsible for significant citrus crop losses worldwide and in some countries the pathogen has a status of quarantine organism (Gottwald et al. 2002). Xac pv. citri infects citrus plants by wounds or stomata and attacks the plant cell with a range of different virulence proteins transported out of the bacterial cell (Brunings and Gabriel 2003). Both the pathogen and its host species are considered to be originated in Asia (Civerolo 1984; Leyns et al. 1984) and thus possess a continuous economic threat in this area.

Considering the importance of this disease, there is a dire need to assess variability in the pathogen population in response to various host species for a better control of the disease (Ali et al. 2017). Variability in pathogen population could be assessed based on inoculation experiments (Schaad et al. 2001), serological tests and molecular assays using DNA based techniques (Alvarez et al. 1991; Gottwald et al. 1991; Sun et al. 2004). Several DNA based assays are presently being used for assessing variability in pathogen populations for crop pathogens (Ali et al. 2017).

Among various DNA based molecular genotyping techniques, RAPD, SSRs, and sequencing techniques are very much useful. Integrated approach that combines bacterial isolation and conventional polymerase chain reaction (PCR) is most powerful techniques that have been adopted for accurate, fast and reliable detection and identification of Xac pv. citri (Shehzadi and Naz 2019). Different sets of primers usually designed for specific and target region of bacteria DNA to check all variations among strains of citrus canker (Katkar et al. 2016).

The present study was designed to assess variability in citrus canker pathogen population using RAPD markers, while considering the role of host (type of citrus). The objectives of the current study were; i): To assess the prevalence of citrus canker on various citrus ecotypes at fruit nurseries of District Peshawar. ii): to isolate and characterize the strains of citrus canker bacteria from fruit nurseries of district Peshawar. iii). To assess the variability in pathogen population in relation to host considering various ecotypes of citrus. The information obtained would be useful for devising appropriate disease management strategy, while considering the level of pathogen diversity and divergence.

\section{Materials and Methods}

The current study was designed to assess variability in the citrus canker pathogen population in relation to citrus host at district Peshawar. The sampling was done at different locations of Peshawar, while the isolation of bacteria, multiplication and genotyping was conducted at of the Genomics and Bioinformatics Division, Institute of Biotechnology and Genetic Engineering, The University of Agriculture Peshawar, Pakistan. Morphological and biochemical based diagnostic methods are available for citrus canker bacteria, but these protocols require skilled personnel and are time consuming Population genetic structure was studied through screening several RAPD genetic markers which showed different diversity levels. In this study, we developed a RAPD based PCR optimized protocol for reliable and robust differentiation of Xac pv. Citri.

\section{Disease surveillance and sampling}

The infestation of disease was assessed in major nurseries of citrus at District Peshawar i.e., UAP Campus (30 samples), Hayatabad (30 samples) and Tarnab farm (30 samples) (Table 1). Infected leaf samples of citrus plants were collected from these three different areas of Peshawar. Samples were appropriately collected in paper bags and were labeled with necessary information e.g., detailed location, host type, plant age and date of sampling. These samples were then shifted to the lab for isolation and purification process.

\section{Isolation of bacteria from the canker lesions}

Leaves with typical canker symptoms were rinsed with distilled water and then bacterial affected part was cut with sterilized blades. The infected part was then surface 
sterilized with $0.9 \%$ Mercuric Chloride and then washed it twice with sterilized water. Dried canker lesions were crushed in phosphate buffer solution containing $137 \mathrm{~m} M$ $\mathrm{NaCl}, 10 \mathrm{~m} M$ phosphate, $2.7 \mathrm{~m} M \mathrm{KCL}$ and $\mathrm{pH} 7.4$ (Pruvost et al. 1992). These macerates were cultured on Petri plates having nutrient agar growth medium containing $0.5 \%$ peptone, $0.3 \%$ yeast extract, $0.5 \% \mathrm{NaCl}$ and $1.5 \%$ agar. Also, added $16 \mathrm{mg}$ cephalexin in the media for the selective growth of canker bacteria. The plates were incubated at $28^{\circ} \mathrm{C}$ in incubator for $72 \mathrm{hrs}$. The cultured bacteria were purified and sub-cultured on agar growth medium. The isolates were further cultured in nutrient agar broth for DNA extraction purpose.

\section{Molecular genotyping of bacterial isolates}

The bacterial suspension in nutrient broth was centrifuged at $6000 \mathrm{rpm}$ for $3 \mathrm{~min}$ and pellet was collected. Total genomic DNA was extracted by re-suspending the bacterial cells in CTAB buffer containing (2\% CTAB, $10 \mathrm{mM}$ Tris $\mathrm{HCl}, 5$ $\mathrm{m} M \mathrm{NaCl}, \quad 1 \mathrm{~m} M$ EDTA, $1 \% \quad \mathrm{PVP}$ and $1 \%$ marceptoethanol) (Ali et al. 2017). The bacterial suspension was then transferred to $1.5 \mathrm{~mL}$ Eppendorf tube and incubated in water bath at $65^{\circ} \mathrm{C}$ for $30 \mathrm{~min}$. Tubes were centrifuged at $12000 \mathrm{rpm}$ for $15 \mathrm{~min}$ and supernatants were transferred to fresh tube. Around $28 \mu \mathrm{L} \mathrm{Na}$ acetate and 750 $\mu 1$ Phenol: Chloroform: Isoamyl alcohol (25:24:1) was added to supernatant and centrifuged at $12000 \mathrm{rpm}$ for 10 min to separate the phases. An upper aqueous layer was transferred to fresh Eppendorf tube and double amount of iso-propanol was added and centrifuged at $12000 \mathrm{rpm}$ for 30 min to allow precipitation. After that, the supernatant was discarded without disturbing the pellet and washed with $70 \%$ ethanol through centrifugation for $7 \mathrm{~min}$ at $12000 \mathrm{rpm}$. The ethanol was discarded and the pellet was air dried. Then $1 \mu \mathrm{L}$ RNAse $(10 \mathrm{mg} / \mathrm{mL})$ and $30 \mu \mathrm{L} \mathrm{TE}(10 \mathrm{~m} M)$ buffer were added to remove RNA. Extracted DNA was stored at $20^{\circ} \mathrm{C}$. DNA concentration was assessed by measuring the optical density (OD) at $260 \mathrm{~nm}$ using Nanodrop. The quality of DNA was examined by gel electrophoresis.

Molecular genotyping of these isolates was done through three RAPD primers using conventional PCR (Table 2). A PCR thermal profile was calibrated for each primer through trying various annealing temperatures. PCR reaction mix for $10 \mu \mathrm{L}$ reaction was prepared for each primer in the PCR tube. It contained $2.8 \mu \mathrm{L}$ of water, $5 \mu \mathrm{L}$ of PCR green master mix, $1 \mu \mathrm{L}$ of single RAPD primer, 0.2 $\mu \mathrm{L}$ of DNA Taq Polymerase and $1 \mu \mathrm{L}$ of DNA sample. The PCR tubes were placed in the PCR machine and subjected to the primer thermal conditions. The PCR amplified products were run on agarose gel and DNA were visualized in the gel documentation system.

\section{Data analysis}

After visualization of gel, the RAPD bands were scored for the polymorphism of various loci, while considering their
Table 1: Surveillance of citrus canker bacterial infestation and sample collection to assess diversity in citrus canker causing bacterial population at district Peshawar

\begin{tabular}{llll}
\hline Sub-location & $\begin{array}{l}\text { Samples } \\
\text { collected }\end{array}$ & $\begin{array}{l}\text { Samples } \\
\text { isolated }\end{array}$ & $\begin{array}{l}\text { Samples } \\
\text { genotyped }\end{array}$ \\
\hline UAP, nurseries & 30 & 6 & 6 \\
Hayatabad nurseries & 30 & 22 & 22 \\
Tarnab Farm nurseries & 30 & 22 & 22 \\
Overall & 90 & 50 & 45 \\
\hline
\end{tabular}

Table 2: Primers sequences and their optimized PCR thermal profiles

\begin{tabular}{llll}
\hline $\begin{array}{l}\text { Primer } \\
\text { Name }\end{array}$ & Gld-18 & Gla-03 & Gla-04 \\
\hline Sequence & ${ }^{\circ}$ GAGAGCCAAC & $3^{5} \mathrm{AGTTCAGCCAC}^{3}$ & ${ }^{\circ} \mathrm{AATCGGGCTG}^{\circ}$ \\
Initial & $95^{\circ} \mathrm{C}$ for $5 \mathrm{~min}$ & $95^{\circ} \mathrm{C}$ for $5 \mathrm{~min}$ & $95^{\circ} \mathrm{C}$ for $5 \mathrm{~min}$ \\
denaturation & & & \\
Denaturation & $95^{\circ} \mathrm{C}$ for $30 \mathrm{~s}$ & $95^{\circ} \mathrm{C}$ for $30 \mathrm{~s}$ & $95^{\circ} \mathrm{C}$ for $30 \mathrm{~s}$ \\
Annealing & $32^{\circ} \mathrm{C}$ for $45 \mathrm{~s}$ & $32^{\circ} \mathrm{C}$ for $45 \mathrm{~s}$ & $32^{\circ} \mathrm{C}$ for $45 \mathrm{~s}$ \\
Extension & $72^{\circ} \mathrm{C}$ for $45 \mathrm{~s}$ & $72^{\circ} \mathrm{C}$ for $45 \mathrm{~s}$ & $72^{\circ} \mathrm{C}$ for $45 \mathrm{~s}$ \\
PCR Cycles & 35 & 35 & 35 \\
Final & $72^{\circ} \mathrm{C}$ for $10 \mathrm{~min}$ & $72^{\circ} \mathrm{C}$ for $10 \mathrm{~min}$ & $72^{\circ} \mathrm{C}$ for $10 \mathrm{~min}$ \\
Extension & & & \\
\hline
\end{tabular}

size in comparison with the ladder. Variability in frequency of various alleles was assessed for isolates originating from various hosts in MS Excel. Population genetic analyses were conducted in POPPR package in R software to assess population subdivision and diversity across various hosts and sub-locations.

\section{Results}

Isolation of the pathogen associated with plant disease is important to know the etiology and management of diseases. The focus of our study was to find variability in citrus canker pathogen population in relation to citrus host types at district Peshawar. The first part of the study involved field sampling, which was done in the fruit nurseries of Malkandair fruit farm, Hayatabad fruit nurseries and Tarnab farm fruit nurseries. Infected citrus plants showed canker lesions on fruits and leaves. Varying level of disease severity was observed on young plants across locations.

Our work revealed diversity and divergence for citrus canker pathogen samples originating from various fruit nurseries of district Peshawar. A total of 35 loci for randomly amplified polymorphic DNA markers were amplified, which enabled to explore genetic diversity and divergence in citrus canker bacterial population, as assessed across locations and over different citrus host types i.e., Sweet Orange, Sour Orange and Lemon.

\section{Feasibility of molecular markers}

For genetic characterization, a total of 35 loci were amplified using a set of four randomly amplified polymorphic DNA markers. The maximum number of loci 
Table 3: Summary statistics for RAPD markers amplified in citrus canker pathogen population from main citrus nurseries of district Peshawar

\begin{tabular}{|c|c|c|c|}
\hline RAPD loci & Gene diversity & Simpsons diversity index & Evenness index \\
\hline GLA-04_500 & 0.27 & 0.27 & 0.67 \\
\hline GLA-04_800 & 0.25 & 0.24 & 0.64 \\
\hline GLA-04_1000 & 0.25 & 0.24 & 0.64 \\
\hline GLA-04_1100 & 0.27 & 0.27 & 0.67 \\
\hline GLA-04_1200 & 0.12 & 0.11 & 0.50 \\
\hline GLA-04_200 & 0.04 & 0.04 & 0.40 \\
\hline GLA-03_100 & 0.12 & 0.11 & 0.50 \\
\hline GLA-03_350 & 0.22 & 0.21 & 0.60 \\
\hline GLA-03_400 & 0.41 & 0.40 & 0.83 \\
\hline GLA-03_500 & 0.43 & 0.42 & 0.86 \\
\hline GLA-03_800 & 0.33 & 0.32 & 0.72 \\
\hline GLA-03_1000 & 0.51 & 0.50 & 0.99 \\
\hline GLA-03_1100 & 0.49 & 0.48 & 0.96 \\
\hline GLA-03_1200 & 0.22 & 0.21 & 0.60 \\
\hline GLA-03_1300 & 0.22 & 0.21 & 0.60 \\
\hline GLA-03_900 & 0.33 & 0.32 & 0.72 \\
\hline GLA-03_700 & 0.43 & 0.42 & 0.86 \\
\hline GLA-03_300 & 0.04 & 0.04 & 0.40 \\
\hline GLB-05_300 & 0.04 & 0.04 & 0.40 \\
\hline GLB-05_400 & 0.12 & 0.11 & 0.50 \\
\hline GLB-05_500 & 0.22 & 0.21 & 0.60 \\
\hline GLB-05_600 & 0.18 & 0.18 & 0.57 \\
\hline GLB-05_700 & 0.35 & 0.34 & 0.75 \\
\hline GLB-05_800 & 0.39 & 0.38 & 0.81 \\
\hline GLB-05_1000 & 0.49 & 0.48 & 0.96 \\
\hline GLB-05_1200 & 0.15 & 0.15 & 0.54 \\
\hline GLB-05_1300 & 0.39 & 0.38 & 0.81 \\
\hline GLB-05_1500 & 0.22 & 0.21 & 0.60 \\
\hline GLB-05_1100 & 0.33 & 0.32 & 0.72 \\
\hline GLD-018_300 & 0.43 & 0.42 & 0.86 \\
\hline GLD-018_500 & 0.22 & 0.21 & 0.60 \\
\hline GLD-018_700 & 0.35 & 0.34 & 0.75 \\
\hline GLD-018_1000 & 0.47 & 0.46 & 0.93 \\
\hline GLD-018_1300 & 0.27 & 0.27 & 0.67 \\
\hline GLD-018_600 & 0.15 & 0.15 & 0.54 \\
\hline
\end{tabular}

(12) was recorded for GLB-03, followed by GLB-05 (11 loci), while GLA-04 and GLD-18 resulted in amplification of 6 loci (Table 3). Plotting of multilocus genotypes against the 35 RAPD loci detected, confirmed the suitability of markers for the detection of variability in the pathogen population of citrus canker (Fig. 1A). It revealed that addition of loci till 22-28 loci added detection of further MLGs, whereas the tested 35 loci were able to detect all of the MLGs present in the dataset. To check the association between the amplified 35 loci, the $r^{2}$ was calculated using pair wise linkage disequilibrium analysis (Fig. 1B). An overall lack of strong linkage was evident across the amplified loci.

The maximum gene diversity $(0.51)$ was recorded for loci GLA-03_1000, followed by GLB-05_1000 and GLA03_1100 (0.49), while the minimum gene diversity $(0.04)$ was observed for locus GLA-04_200. The maximum diversity index (0.50) was recorded for loci GLA-03_1000, followed by GLB-05_1000 and GLA-03_1100 (0.48), while the minimum diversity index $(0.04)$ was observed for locus GLA-04_200, GLA-03_300 and GLB-05_300. The maximum evenness index $(0.99)$ was observed for GLA-

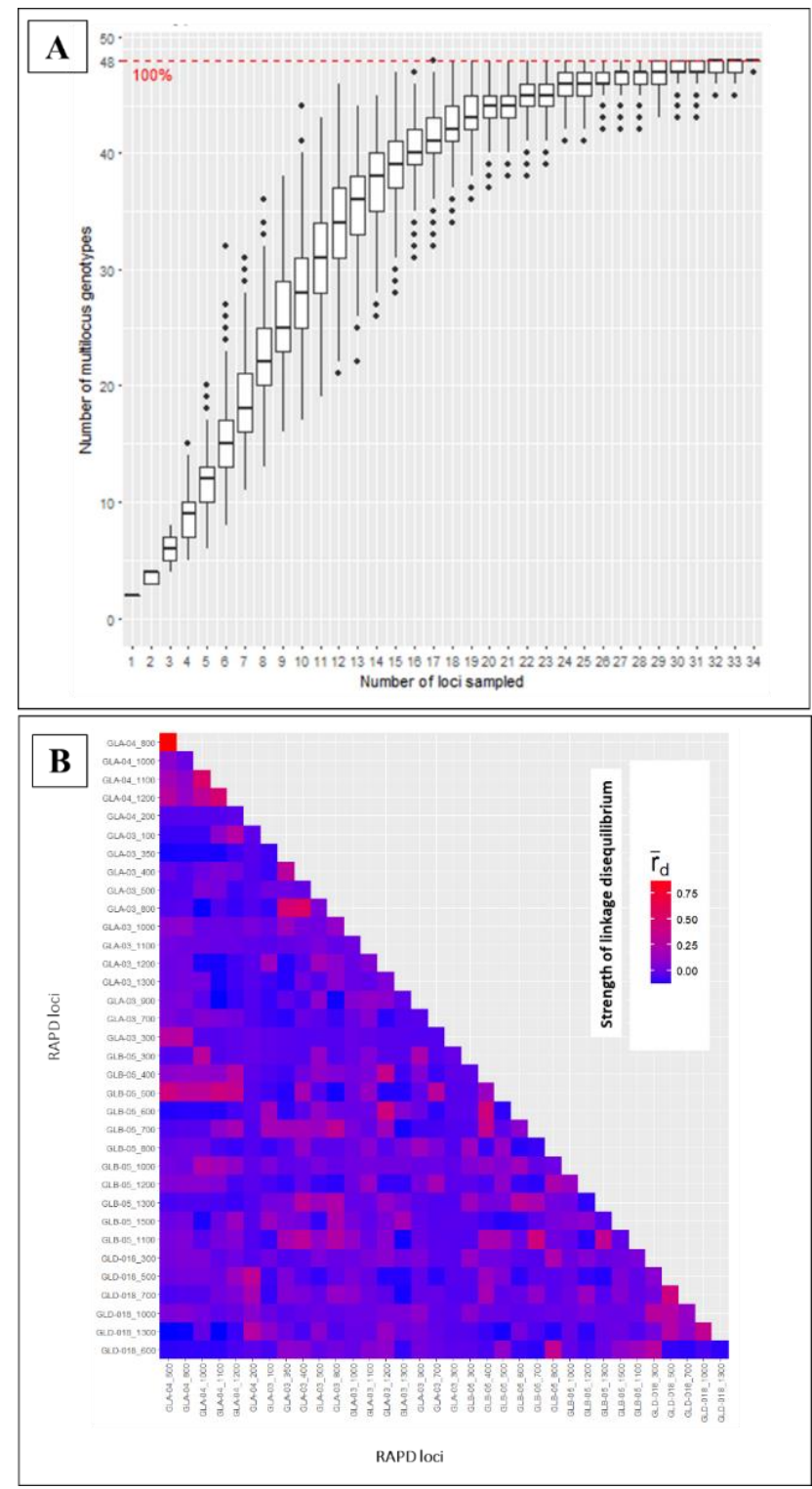

Fig. 1: Feasibility of RAPD markers for assessment of diversity and divergence in citrus canker pathogen population as revealed through (A) detection of multilocus genotype against the loci resampled, and (B) the association among different RAPD loci

03_1000 while minimum evenness $(0.40)$ was recorded for locus GLA-04_200, GLA-03_300 and GLB-05_300.

\section{Divergence and diversity across locations}

Divergence of isolates sampled from different locations was assessed through principal component analysis, principal coordinate analysis, neighbor joining tree and network analysis. The principal component analysis considering information on sample location, revealed a weak divergence across locations (Fig. 2A). The first component explained $11.37 \%$ of the variation while the second component 

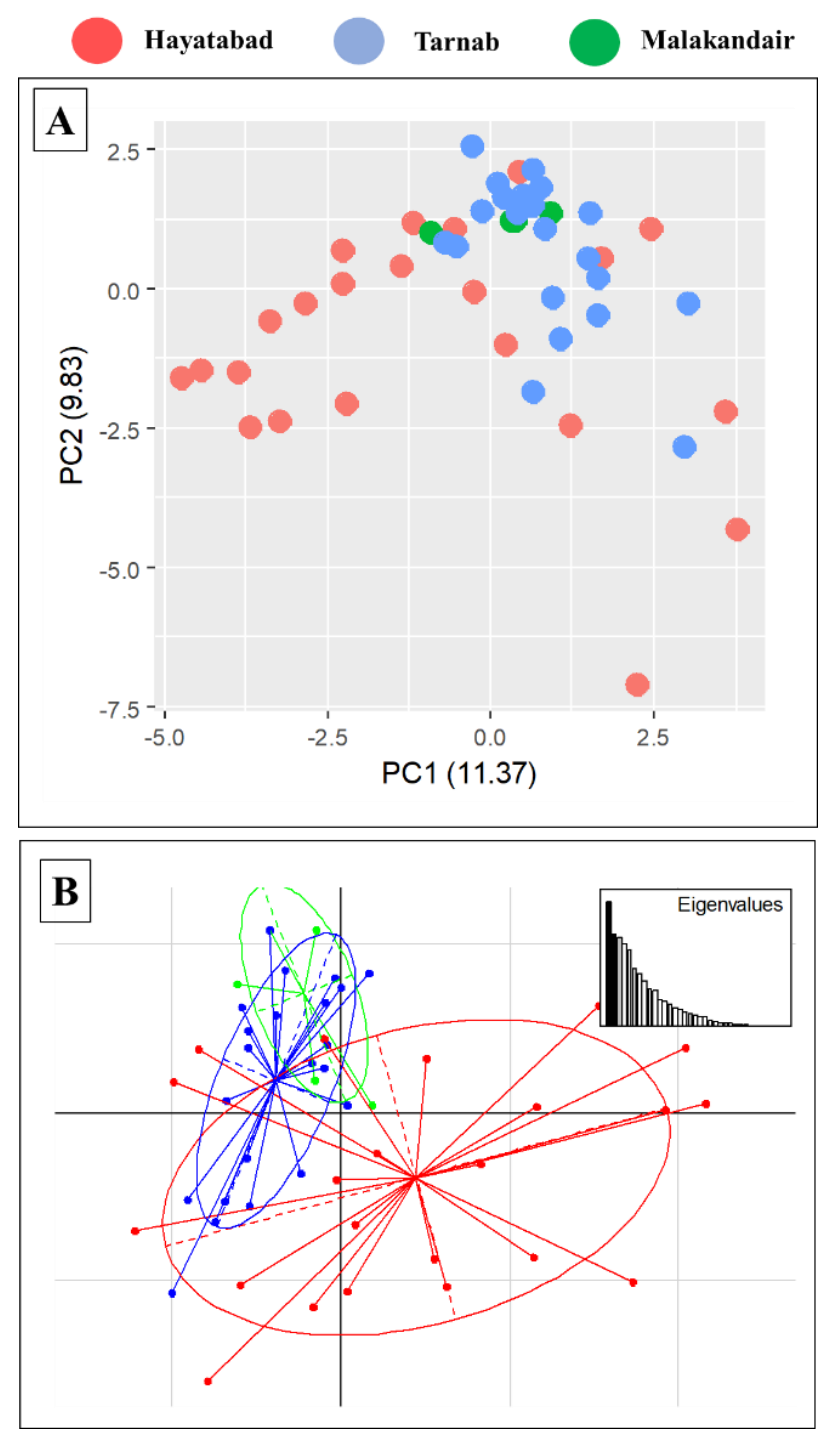

Fig. 2: Divergence among citrus canker population from various locations of main citrus nurseries of district Peshawar, as revealed by Principal component analyses (A) and Principle co-ordinate analyses (B)

contributed $9.83 \%$, with an overall component contribution of $21.2 \%$ (Fig. 2A). The divergence was further elaborated by principle coordinate analysis, where the samples from different locations were clustered together with limited overlap across locations, particularly for the samples from Hayatabad, which were dispersed (Fig. 2B). Interestingly, the samples from Malakandair nursery were clearly divergent from Hayatabad, though had overlapping with the samples from Tarnab farm nurseries. The neighbour joining phylogenetic tree further confirmed this pattern of divergence and population subdivision (Fig. 3A). Most of the isolates from the Hayatabad nurseries were present on separate phylogenetic clades, while that of Tarnab farm nurseries were grouped together, although some of the isolates were positioned on at the clade specific to another
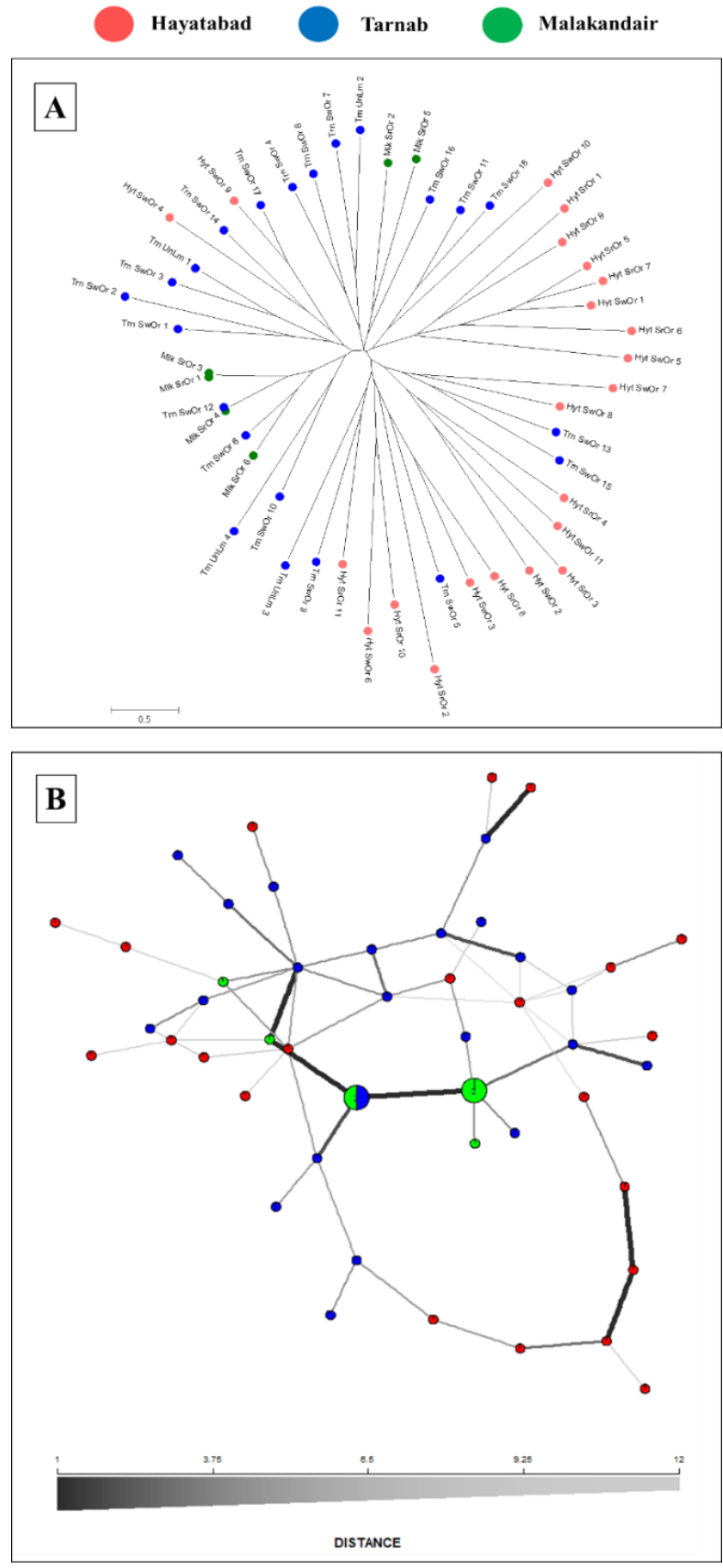

Fig. 3: Divergence among citrus canker population from various locations of main citrus nurseries of district Peshawar, as revealed by Neighbor-joining (NJ) tree (A) and Network Analyses (B)

location. The citrus canker pathogen isolates sampled from Malakandair farm, were grouped in the middle of the clades from the two locations (Fig. 3A). This pattern of divergence was further elucidated by the network analyses, where multiple linking networks were possible with samples from Malakandair positioned in the middle of network (Fig. 3B).

An overall high diversity was estimated for the citrus canker pathogen population sampled from various fruit nurseries of district Peshawar (Table 4). A total of 49 MLGs 
Diversity in X. citri on Citrus Hosts / Intl J Agric Biol, Vol 25, No 6, 2021

Table 4: Diversity parameters observed for citrus canker population from various locations of main citrus nurseries of district Peshawar

\begin{tabular}{lllllll}
\hline Location & Sample size & Distinct MLGs detected & Gene diversity & Genotypic diversity & Evenness index & Linkage disequilibrium \\
Hayatabad & 22 & 22 & 0.336 & 0.955 & 1.000 & 0.020 \\
Malkandair & 6 & 5 & 0.099 & 0.778 & 0.930 & 0.159 \\
Tarnab & 22 & 22 & 0.221 & 0.955 & 1.000 & 0.006 \\
Overall Peshawar & 50 & 49 & 0.276 & 0.978 & 0.978 & 0.022 \\
\hline
\end{tabular}
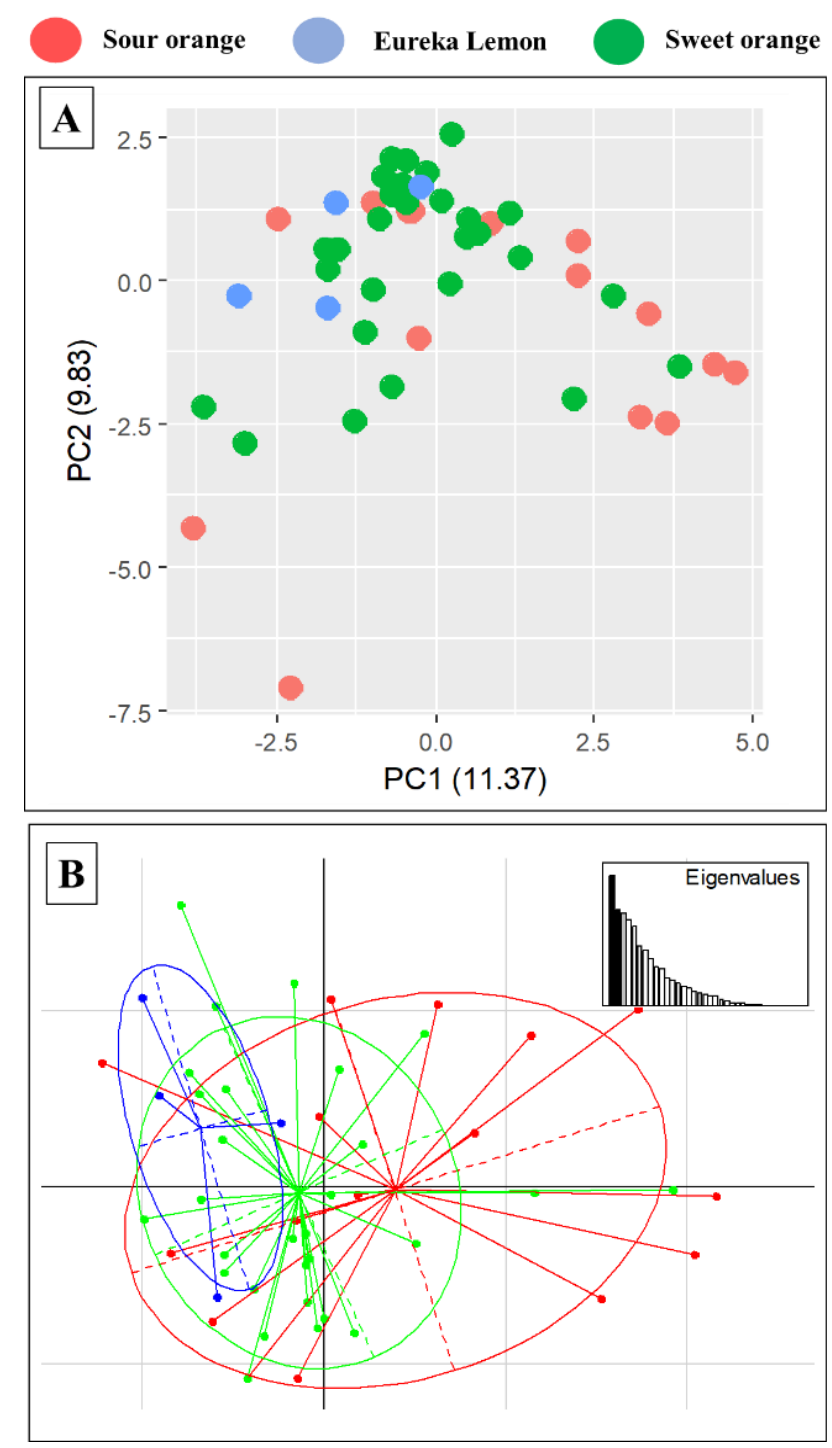

Fig. 4: Divergence among citrus canker population from various citrus host types sampled at Peshawar, as revealed by Principal component analyses $(\mathbf{A})$ and Principal co-ordinate analyses $(\mathbf{B})$

was observed out of 50, samples where each isolate represented distinct MLG, except a couple of isolates, which were identical. At Hayatabad and Tarnab Farm, all of the genotyped isolates represented distinct multilocus genotypes (22MLGs out of 22 samples), while at Malakandair nursery five distinct MLGs were detected out of 6 samples (Table 4). The genotypic diversity ranged from 0.778 (detected at Malakandair) to 0.955 (detected at Hayatabad and Tarnab), with an overall value of 0.978 (Table 4). The maximum gene diversity was detected at Hayatabad (0.336) and the minimum was detected at Malkandar (0.099) with an overall diversity of 0.276 , respectively. The maximum linkage disequilibrium was observed for samples collected from Malkandair location whereas the minimum linkage disequilibrium was observed for samples collected from Tarnab location (Table 4). The very small linkage disequilibrium value reflected on the potential recombination in the citrus canker bacterial population in the region, which must have direct implications to disease management and resistance exploitation at the fruit orchards level.

\section{Divergence and diversity across various citrus host types}

To assess the role of host on divergence among citrus canker bacterial isolates, both principal component analyses and principal coordinate analyses were conducted, using information on host of origin of the samples, considering their genotypic profile over the 35 RAPD loci. In the principal component analyses, the first component contributed $(11.37 \%)$ while second components contributed $(9.83 \%)$ with an overall component contribution was $21.2 \%$, however, no clear divergence was evident for host of origin (Fig 4A). Isolates from various hosts were dispersed together on the principal component analyses. This was further supported by the principal coordinate analysis, where no clear groups were detected, and all the citrus canker bacterial samples were dispersed having overlap with one another (Fig. 4B). The neighbour joining phylogenetic tree was constructed considering information on host of origin, which revealed the lack of such adivergence due to host among citrus canker bacterial population from various citrus host types sampled at Peshawar (Fig. 5A). Samples originated from various hosts were equally dispersed across various phylogenetic clades on the phylogenetic tree. The lack of host dependent population subdivision was further confirmed by the network analyses, where samples originated from multiple hosts were dispersed across the network and none of the part was specific to a given host in the network analyses conducted based on 35 RAPD loci (Fig. 5B).

To assess whether a single or few host specific lineages are prevalent on various citrus host, or diverse lineages can grow on different citrus hosts, diversity parameters were assessed for samples grouped as their host of origin. High diversity was observed for the citrus canker population from various citrus host types sampled at Peshawar (Table 5). Every citrus host represented a diverse set of multilocus genotypes i.e., 49 MLGs were observed out of 50 genotyped samples. The genotype diversity ranged 
Ullah et al. / Intl J Agric Biol, Vol 25, No 6, 2021

Table 5: Diversity parameters observed for citrus canker population from various citrus host types sampled at Peshawar

\begin{tabular}{lllllll}
\hline Population & Sample size & Distinct MLGs detected & Gene diversity & Genotypic diversity & Evenness index & Linkage disequilibrium \\
\hline Sour Orange & 17 & 16 & 0.282 & 0.934 & 0.969 & 0.059 \\
Sweet Orange & 29 & 29 & 0.264 & 0.966 & 1.000 & 0.013 \\
Eureka Lemon & 4 & 4 & 0.281 & 0.750 & 1.000 & 0.000 \\
Overall population & 50 & 49 & 0.276 & 0.978 & 0.978 & 0.022 \\
\hline
\end{tabular}
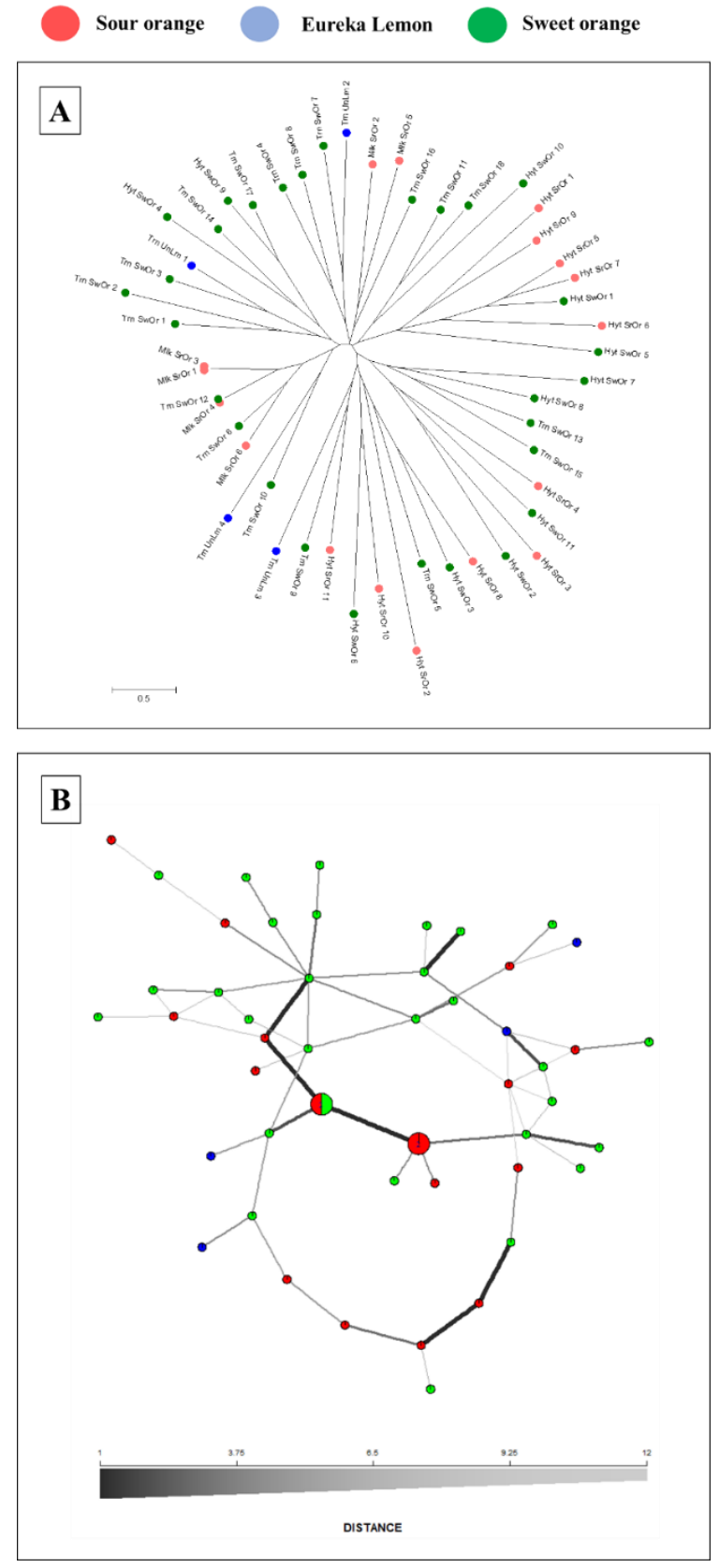

Fig. 5: Divergence among citrus canker population from various citrus host types sampled at Peshawar, as revealed by Neighborjoining (NJ) tree (A) and Network Analyses (B)

from 0.750 (for Unika Lemon) to 0.966 (for sweet orange) with an average of 0.978 , while maximum gene diversity was detected for samples from sour orange (0.282) and minimum was detected for samples from sweet orange (0.264) with an overall diversity of 0.276 , respectively. The maximum linkage disequilibrium (0.059) was observed for sour orange whereas the minimum linkage disequilibrium was observed for Unika Lemon (0.000).

\section{Discussion}

Citrus canker Disease incidence and severity remains variable due to differences in environmental condition in pathogen survival (Honger et al. 2016). The similar variations were observed in the current study (Strayer et al. 2016). The detection of genetic differences on the basis of molecular markers provides fast and more detailed results as compared to other methods (Simoes et al. 2007).

The selected marker confirmed its suitability for the detection of diversity and divergence in citrus population. In our research, we detected a high level of polymorphism and also detected 35 loci overall with an average of 8.7 bands per loci. Our current study was in accordance with the results of Katkar et al. (2016) who studied the diversity among the isolates of Xac pv. citri collected from different agro-climate regions of India. Larrea et al. (2018) studied Xanthomanas species of different plants by using type 3 secretion systems. These isolates were grouped together on the basis of different geographical location and with limited genetic differences. Kharde et al. (2018) collected different isolates of $X$. axonopodis from different places in Maharashtra state, India and used morphological, biochemical and RAPD based analysis. They detected 100\% polymorphism on the basis of both RAPD and ISSR markers.

Diversity was higher across all sampling locations as revealed by different diversity indices. Gadhe et al. (2016) detected high genetic variability across multiple geographical locations. Variable diversity across location would reflect on the differential potential of adaptation of the pathogen to host resistance and disease management strategy (Ali et al. 2014).

The high diversity was accompanied by an overall lack of strong linkage disequilibrium, which reflects on the potential role of recombination in these bacteria. Contrary to this study, Ngoc et al. (2007) detected significant level of linkage disequilibrium among molecular markers loci, suggesting absence of frequent genetic exchange in the bacterial populations they studied. This result would have a direct implication for disease management, as higher recombination would enable rapid adaptation of pathogen strains to host resistance (Ali et al. 2014). 
Divergence of isolates sampled from different locations was present albeit weak, as assessed through principal component analysis, principal coordinate analysis, neighbor joining tree and network analysis. These analyses showed that there was a weak pattern of divergence and the samples were equally distributed across locations. Cuberto and Graham (2002), reported some distinct isolates of Xanthomonas from some restricted areas in Malaysia and China which were grouped separately from the rest of canker isolates using PCR fingerprinting techniques and also showed similarity with a few diverse samples infecting in Florida. Considering, the distribution of isolates on principle component and principle coordinate analyses, the bacterial strains of all three locations were not clustered in separate groups, but rather had a dispersed assignment to three clusters. Similar results were obtained in southeastern Nigeria strains where four bacteria were not clustered on the basis of PCA (Ogunjobi 2006). Analyzed 50 bacterial strains and their similarity based on the principal components and coordinate analysis showed that clearly separated in to two components.

While analysing the population structure due to host, a lack of host dependent population subdivision was confirmed by the PCA, PCoA, phylogenetic tree and network analyses, where in samples originated from multiple host, no host specific clusters were identified (Fig. 3B). This is an interesting result, suggesting that the pathogen can cross inoculate various host types and thus overcome the host resistance (Shehzadi and Naz 2019; Patane et al. 2019). Host specific lineages have been reported for pathogens in various crops, particularly the fungal pathogens like rice blast fungi (Gladieux et al. 2018).

Interestingly, diversity assessment for isolates originating on various host revealed that not a single or few host specific lineages were prevalent on different citrus host types, but rather a diverse population were prevalent on different citrus hosts. This could be the result of high recombination in a diverse population (Ali et al. 2014), which results in independent evolution of pathogen variants to acquire virulence against different host species.

Our results on diversity and divergence detected for isolates sampled on various hosts revealed high diversity on all the citrus host species, while the divergence was absent across different host types. The study based on host specific and location specific population genetic structure seem to be complementary to one another and also informative to draw the genetic structure of Xac pv. citri. The information generated from the current findings would be useful for understanding molecular mechanism of pathogenicity and devising a better disease management strategy.

\section{Conclusion}

From the findings of the study, it can be concluded that divergence across host was absent. The overall high diversity and very small linkage disequilibrium revealed a potential role of recombination in the population. Future disease management must consider this high diversity and recombination in the pathogen population. Future studies must be made to assess the diversity divergence across the province and country with more robust sampling.

\section{Acknowledgements}

The work received resources from the project awarded by the US Department of Agriculture, Agricultural Research Service, under agreement No. 58-0206-0-171 F.

\section{Author Contributions}

The study was designed by MA, MZ, IJ and SA. Surveillance and Sampling was done by SU, LJ, ZR and MRK. Bacterial isolation and characterization was done by SU, LJ and MA. Molecular Genotyping was done by SU, LJ, ZR, AI and MNK. Population genetics analyses were done by SU, LJ and SA. Resources for the study were provided by MA, MRK, IJ and SA. The manuscript was written by SU, LJ, AI, MZ, MNK and SA. All authors revised and approved the manuscript.

\section{Conflict of interest}

The authors declare that they have no conflict of interest.

\section{Data Availability}

The data will be made avaialble on requests to the corresponding author.

\section{Ethics Approval}

Not applicable.

\section{References}

Ali MR, MF Hasan, RS Lia, A Akter, MSE Sumi, MF Hossain, B Sikdar (2017). Isolation and characterization of a canker disease causing pathogen from Citrus aurantifolia and evaluation of its biological control measure. J Entomol Zool Stud 5:1526-1532

Ali S, P Gladieux, M Leconte, A Gautier, AF Justesen, MS Hovmøller, J Enjalbert, CD Vallavieille-Pope (2014). Origin, migration routes and worldwide population genetic structure of the wheat yellow rust pathogen Puccinia striiformis $f$. spp. tritici. PLoS Pathog 10; Article e1003903

Alvarez A, A Benedict, C Mizumoto, L Pollard, E Civerolo (1991). Analysis of Xanthomonas campestris $p v$. citri and $X$. c. citrumelo with monoclonal antibodies. Phytopathology 81:857-865

AraujoEFD, LPD Queiroz, MA Machado (2003). What is citrus? Taxonomic implications from a study of cp-DNA evolution in the tribe Citreae (Rutaceae subfamily Aurantioideae). Org Divers Evol 3:55-62

Brunings AM and DW Gabriel (2003). Xanthomonas citri: Breaking the surface. Mol Plant Pathol 4:141-157

Civerolo E (1984). Bacterial canker disease of citrus (Xanthomonas campestris). J Rio Grand Vall Hortic Assoc 37:127-146

Cuberto J, JH Graham (2002). Genetic relationship among worldwide strains of Xanthomonas causing canker in citrus species and design of new primers. Appl Environ Microbiol 68:1257-1264 
Das A (2003). Citrus canker-A review. J Appl Hortic 5:52-60

Graham JH, M Dewdney (2014). Brown rot of fruit. In: Florida citrus pest management guide, pp:67-68. Lake alfred, university of FloridaGadhe SK, SH Antre, BB Ghorpade, RH Autade, RR Mandlik (2016). Studies on molecular variability among Xanthomonas axonopodis pv. punicae isolates collected from Different Locations. Intl J Pure Appl Biosci 4:160-166

Gladieux P, B Condon, S Ravel, D Soanes, JL Maciel, A Nhani, L Chen, R Terauchi, MH Lebrun, D Tharreau, T Mitchell, KF Pedley, B Valent, NJ Talbot, M Farman, E Fournier (2018). Gene flow between divergent cereal-and grass-specific lineages of the rice blast fungus Magnaporthe oryzae. Amer Soc Microbiol 9; Article e01219-17

Gottwald TR, JH Graham, TS Schubert (2002). Citrus canker: The pathogen and its impact. Plant Health Progr 3:15-48

Gottwald TR, A Alvarez, J Hartung, A Benedict (1991). Diversity of Xanthomonas campestris pv. citrumelo strains associated with epidemics of citrus bacterial spot in Florida citrus nurseries: Correlation of detached leaf, monoclonal antibody, and restriction fragment length polymorphism assays. Phytopathology 81:749-753

Graham J, T Gottwald, T Riley, J Cubero, D Drouillard (2000). Survival of Xanthomonas campestris pv. citri $(\mathrm{Xcc})$ on various surfaces and chemical control of Asiatic citrus canker (ACC). In: Proceedings of the Intern. Citrus Canker Research Workshop, Florida. June 20-22, 2000, Ft. Pierce, Florida, USA

Honger JO, E Essuman, EW Cornelius (2016). The Incidence, severity and etiology of a bacterial canker disease of citrus in Ghana. West Afr J Appl Ecol 24:31-44

Kahn T, R Krueger, D Gumpf, M Roose, ML Arpaia, T Batkin, S Cockerham (2001). Citrus genetic resources in california: analysis and recommendations for long-term conservation. Report of the Citrus Genetic Resources Assessment Task Force. Division of Agriculture and Natural Resources, University of California, Davis, California, USA

Katkar M, KS Raghuwanshi, VP Chimote, SG Borkar (2016). Pathological, Bio-chemical and Molecular diversity amongst the isolates of Xanthomonas axonopodis pv. citri causing citrus canker in acid lime from different agro-climatic region of India. Intl J Environ Agric Biotech 1; Article 1.2.25

Kharde RR, SA Lavale, BB Ghorpade (2018). Molecular diversity among the isolates of Xanthomonas axonopodis pv. citri causing bacterial canker in citrus. Intl J Curr Microbiol Appl Sci 7:2375-2384

Larrea SA, U Dhakal, G Boluk, L Fatdal, A Alvarez, A Strayer-Scherer, M Paret, J Jones, D Jenkins, M Arif (2018). Development of a genomeinformed loop-mediated isothermal amplification assay for rapid and specific detection of Xanthomonas euvesicatoria. Sci Rep 8; Article 14298

Leyns F, MD Cleene, JG Swings, JD Ley (1984). The host range of the genus Xanthomonas. Bot Rev 50:308-356
Memon N (2017). Citrus fruit (Kino). Exclusive on Kino. Pak Food J 7:29-31

Ngoc LBT, C Vernière, O Pruvost, N Kositcharoenkul, S Phawichit (2007). First report in Thailand of Xanthomonas axonopodis pv. citri-A* causing citrus canker on lime. Plant Dis 91:771-771

Ogunjobi AA (2006). Molecular variation in population structure of Xanthomonas axonopodis pv manihotis in the south eastern Nigeria. Afr J Biotechnol 5:1868-1872

Patane JS, J Martins, LT Rangel, J Belasque, LA Digiampietri, AP Facincani, NF Almeida (2019). Origin and diversification of Xanthomonas citri subspp. citri pathotypes revealed by inclusive phylogenomic, dating, and biogeographic analyses. BMC Genomics 20; Article 700

Pruvost O, JS Hartung, EL Civerelo, C Dubois, X Perrier (1992). Plasmid DNA fingerprinting distinguished pathotypes of Xanthomanas compestris. J. Phytopathol 82:485-490

Schaad NW, JB Jones, W Chun (2001). Laboratory Guide for the Identification of Plant Pathogenic Vacteria, $3^{\text {rd }}$ edn. American Phytopathology Society, Saint Paul, Minnesota, USA

Schubert TS, JW Miller (1996). Bacterial citrus canker Fla. Department Agric and Consumer Services, Division of Plant Industry, Canberra, Australia

Shehzadi I, S Naz (2019). Morphological, biochemical and genetic characterization of citrus canker pathogen (Xanthomonas axonopodis) from citrus cultivars of Punjab, Pakistan. J Anim Plant Sci 29:117-124

Siddique MI, E Garnevska (2018). Citrus Value Chain(s): A survey of Pakistan citrus industry. Agric Value Chain 26; Article 37

Silva ARD, JA Ferro, FDC Reinach, CS Farah, LR Furlan, RB Quaggio, L Alves (2002). Comparison of the genomes of two Xanthomonas pathogens with differing host specificities. Nature 417:459-463

Simoes TH, ER Gonçalves, YB Rosato, A Mehta (2007). Differentiation of Xanthomonas species by PCR-RFLP of rpf B and atp D genes. FEMS Microbiol Lett 271:33-39

Strayer AL, A Jeyaprakash, GV Minsavage, S Timilsina, GE Vallad, JB Jones, ML Paret (2016). A multiplex real-time PCR assay differentiates four Xanthomonas species associated with bacterial spot of tomato. Plant Dis 100:1660-1668

Sun X, RE Stall, JB Jones, J Cubero, TR Gottwald, JH Graham, VK Stromberg (2004). Detection and characterisation of a new strain of citrus canker bacteria from Key/Mexican lime and alemow in South Florida. Plant Dis 88:1179-1188

Ulubelde M (1985). Turunçgillerin taksonomisi. Ege Bölg Zir Arast Enst Yayınl 55:43

Vernière C, J Hartung, O Pruvost, E Civerolo, AM Alvarez, P Maestri, J Luisetti 1998. Characterization of phenotypically distinct strains of Xanthomonas axonopodis pv. citri from Southwest Asia. Eur J Plant Pathol 104:477-487 